\title{
Carotenoid-Derived Flavor Precursors from Averrhoa carambola Fresh Fruit
}

\author{
Xuchao Jia ${ }^{1,2,+}$, Dan Yang ${ }^{2,3, \dagger}$, Yue Yang ${ }^{2,4}$ and Haihui Xie ${ }^{2, *}$ (D) \\ 1 Sericultural \& Agri-Food Research Institute, Guangdong Academy of Agricultural Sciences/Key Laboratory \\ of Functional Foods, Ministry of Agriculture and Rural Affairs/Guangdong Key Laboratory of Agricultural \\ Products Processing, Guangzhou 510610, China; jiaxuchao@gdaas.cn \\ 2 South China Botanical Garden, Chinese Academy of Sciences/Guangdong Provincial Key Laboratory of \\ Applied Botany/Key Laboratory of South China Agricultural Plant Molecular Analysis and Genetic \\ Improvement, Guangzhou 510650, China; yangdan89@mail.jnmc.edu.cn (D.Y.); \\ yangyue115@scbg.ac.cn (Y.Y.) \\ 3 School of Public Health, Jining Medical University, Jining 272067, China \\ 4 College of Life Sciences, University of Chinese Academy of Sciences, Beijing 100049, China \\ * Correspondence: xiehaih@scbg.ac.cn; Tel.: +86-20-37080950 \\ + These authors contributed equally to this study.
}

Received: 22 November 2018; Accepted: 8 January 2019; Published: 11 January 2019

\begin{abstract}
The fruit of Averrhoa carambola L. (Oxalidaceae), commonly known as star fruit or carambola, is popular in tropical and subtropical regions. Carotenoid-derived components, mainly $\mathrm{C}_{13}-$ and $\mathrm{C}_{15}$-norisoprenoids, contribute greatly to the flavor of star fruit. Previously reported norisoprenoids were tentatively identified by GC-MS analysis after enzymatic hydrolysis. To gain accurate information about glycosidically bound flavor precursors in star fruit, a phytochemical study was conducted, which led to the isolation of 16 carotenoid derivatives-One new $\mathrm{C}_{13}$-norisoprenoid glucoside, (5R,6S,7E,9R)-5,6,9-trihydroxy-7-megastigmene 9-O- $\beta$-D-glucoside (1); one new $\mathrm{C}_{15}$-norisoprenoid, $(6 S, 7 E, 10 S)-\Delta^{9,15}-10$-hydroxyabscisic alcohol (11); and 14 known ones, of which 12 were in glucoside form. The structures of the two new compounds were elucidated on the basis of extensive spectroscopic data analysis and chemical reaction. Compound $\mathbf{1 1}$ was a rare $\mathrm{C}_{15}$-norisoprenoid with a double bond between C-9 and C-15, and its possible biogenetic pathway was proposed. The known compounds were identified by comparison of their mass and nuclear magnetic resonance (NMR) data with those reported in the literature. The structure identification of one new (1) and seven known $(\mathbf{3}-\mathbf{7 ,}, \mathbf{9}$, and 10) $\mathrm{C}_{13}$-norisoprenoid glucosides from the genus Averrhoa for the first time enriches the knowledge of carotenoid-derived flavor precursors in star fruit.
\end{abstract}

Keywords: Averrhoa carambola; star fruit; flavor precursor; $\mathrm{C}_{13}$-norisoprenoid glucoside; $\mathrm{C}_{15}$ norisoprenoid

\section{Introduction}

Averrhoa carambola L., belonging to the family Oxalidaceae, is widely cultivated in Southeast Asia, China, and India. Its fruit, commonly known as star fruit or carambola, is popular in tropical and subtropical regions and consumed mostly as fresh fruit [1]. The volatile components of star fruit have been extensively studied and approximately 200 aroma components have previously been reported [2-4]. Volatile carotenoid breakdown products play an important role in the flavor of star fruit. However, $\beta$-ionone and $\beta$-ionol were detected as the only two $C_{13}$-norisoprenoids from star fruit until MacLeod and Ames [4] reported $14 \mathrm{C}_{13}$ - and $\mathrm{C}_{15}$-aroma compounds by using the simultaneous distillation/extraction (SDE) method. Star fruit extract was subjected to SDE treatment and almond glucosidase hydrolysis by Herderich et al. [5], which liberated $29 \mathrm{C}_{13}$-aroma compounds, 
indicating that these carotenoid-derived flavor components are derived from non-volatile flavorless glycosidic precursors and that vigorous isolation techniques such as SDE have a high probability of liberating $\mathrm{C}_{13}$-aroma components. The $\mathrm{C}_{13}$-norisoprenoid aroma components of star fruit have been well studied for their attractive sensory qualities and low flavor thresholds. However, the structural information about their glycosidically bound precursors is deficient, and hitherto only three ionone peracetylated glycosides have been isolated from star fruit and structurally identified by mass and NMR measurements [6,7]. Therefore, there is a need to study the accurate structural information of the precursors of these carotenoid-derived components. In the present study, $10 \mathrm{C}_{13}$ - and 6 $\mathrm{C}_{15}$-norisoprenoid compounds including two new ones $(\mathbf{1}$ and 11) were isolated from fresh star fruit (Figure 1), and their structures were elucidated by spectroscopic methods. These findings enrich the knowledge of carotenoid-derived flavor precursors in star fruit.

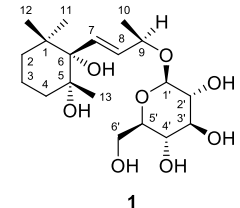<smiles>CC(=O)/C=C/C1(C)C(C)=CC(=O)CC1(C)C</smiles>

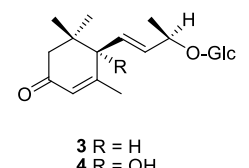<smiles>CO[C@H](C)C/C=C1/C(C)=CC(=O)CC1(C)C</smiles><smiles>CO[C@@H]1C[C@@H](O)C(=CC(=O)C(C)=O)C(C)(C)C1</smiles><smiles>CO[C@@H]1C[C@H](C)[C@](O)(/C=C/C(C)=O)C(C)(C)C1</smiles>
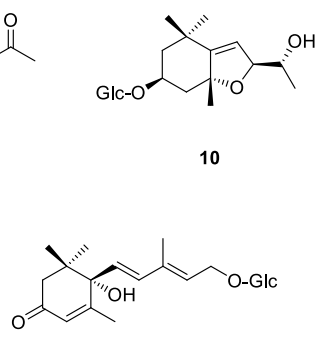

16<smiles>CO[C@H](C)/C=C/C1=C(C)C(=O)CCC1(C)C</smiles><smiles>CC1=CC(=O)CC(C)(C)C1(C)C=CC(=N)C(O)CO</smiles>

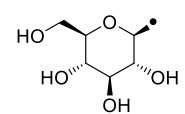

GIC $=\beta$-D-glucopyranosyl

Figure 1. Chemical structures of compounds 1-16.

\section{Results and Discussion}

Compound 1 was obtained as colorless oil and deduced to have the molecular formula $\mathrm{C}_{19} \mathrm{H}_{34} \mathrm{O}_{8}$ based on the high-resolution electrospray ionization mass spectrometry (HR-ESI-MS) datum at $\mathrm{m} / \mathrm{z}$ $389.4614[\mathrm{M}-\mathrm{H}]^{-}$(calculated for $\mathrm{C}_{19} \mathrm{H}_{33} \mathrm{O}_{8}{ }^{-}$, 389.4605) (Figure 2). The ${ }^{1} \mathrm{H}$ and ${ }^{13} \mathrm{C}$ NMR spectra (Table 1), coupled with heteronuclear single quantum coherence (HSQC) analysis, showed signals of four methyls, four methylenes, eight methines, and three quaternary carbons. The signals of $\delta_{\mathrm{H}} 4.36\left(1 \mathrm{H}, \mathrm{d}, J=7.8 \mathrm{~Hz}, \mathrm{H}-1^{\prime}\right)$ and $\delta_{\mathrm{C}} 102.6\left(\mathrm{C}-1^{\prime}\right), 75.4\left(\mathrm{C}-2^{\prime}\right), 77.9\left(\mathrm{C}-3^{\prime}\right), 71.5\left(\mathrm{C}-4^{\prime}\right), 78.1\left(\mathrm{C}-5^{\prime}\right)$, and $62.5\left(\mathrm{C}-6^{\prime}\right)$ were typical of a $\beta$-glucosyl moiety. Apart from these signals, the remaining NMR data were in accordance with those of 7-megastigmene-5,6,9-triol [8] except for the remarkable downshift of C-9 at $\delta 78.4$, which suggested that the $\beta$-glucosyl moiety was attached to C-9 [9]. This deduction was confirmed by the heteronuclear multiple bond correlation (HMBC) spectrum (Figure 3), in which the correlations from $\mathrm{H}-1^{\prime}$ to $\delta_{\mathrm{C}} 78.4$ (C-9) and $\delta_{\mathrm{H}} 4.42$ (H-9) to C-1' were observed. In the nuclear overhauser effect spectroscopy (NOESY) spectrum (Figure 3 ), the presence of obvious correlations between $\delta_{\mathrm{H}} 1.20\left(3 \mathrm{H}, \mathrm{s}, \mathrm{H}_{3}-13\right)$ and $6.15(1 \mathrm{H}, \mathrm{d}, J=15.9 \mathrm{~Hz}, \mathrm{H}-7), \mathrm{H}-7$ and $\delta_{\mathrm{H}} 1.08$ ( $\left.3 \mathrm{H}, \mathrm{s}, \mathrm{H}_{3}-12\right), \mathrm{H}_{3}-12$ and $\mathrm{H}_{3}-13$ suggested that $\mathrm{H}-7, \mathrm{H}_{3}-12$, and $\mathrm{H}_{3}-13$ were in the same orientation. Since the circular dichroism (CD) spectrum (Figure 4) showed a positive Cotton effect at $243 \mathrm{~nm}$, C-6 was determined to have an $S$ absolute configuration [10]. The absolute configuration of C-9 was determined as $R$ based on the empirical rule summarized by Matsunami et al., in which the $\delta$ values (in $\mathrm{CD}_{3} \mathrm{OD}$ ) of $\mathrm{C}-9, \mathrm{C}-10$, and $\mathrm{C}-\mathbf{1}^{\prime}$ ranged from 77.3-79.1, 21.2-21.8, and 102.2-103.0 in $9 R$ versus 74.7-76.3, 22.3-22.6, and 100.5-101.7 in 9S [11]. Acid hydrolysis of 1 yielded D-glucose (retention time $\left(t_{R}\right)=21.2 \mathrm{~min}$ ), which was ascertained by comparison of its $t_{R}$ value with those of authentic D-glucose 
$\left(t_{\mathrm{R}}=21.3 \mathrm{~min}\right)$ and L-glucose $\left(t_{\mathrm{R}}=19.3 \mathrm{~min}\right)$ (Figure 5$)$. Consequently, compound 1 was determined as $(5 R, 6 S, 7 E, 9 R)-5,6,9$-trihydroxy-7-megastigmene 9-O- $\beta$-D-glucoside.

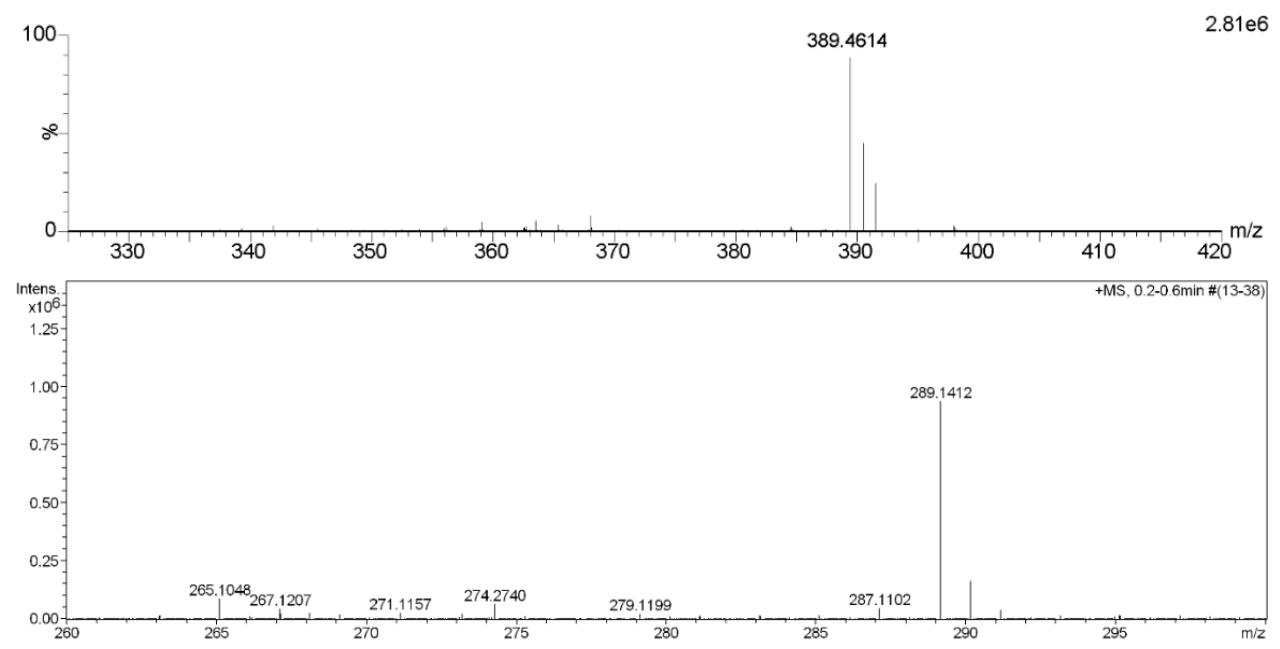

Figure 2. HR-ESI-MS spectra of compounds $\mathbf{1}$ (upper) and 11.

Table 1. ${ }^{1} \mathrm{H}$ and ${ }^{13} \mathrm{C}$ NMR data of compounds 1 and 11 in $\mathrm{CD}_{3} \mathrm{OD}$.

\begin{tabular}{|c|c|c|c|c|}
\hline \multirow{2}{*}{$\mathrm{H} / \mathrm{C}$} & \multicolumn{2}{|l|}{1} & \multicolumn{2}{|l|}{11} \\
\hline & $\delta_{\mathrm{H}}($ mult, $J$ in $\mathrm{Hz})$ & $\delta_{C}$ & $\delta_{\mathrm{H}}(\mathrm{mult}, J$ in $\mathrm{Hz})$ & $\delta_{\mathrm{C}}$ \\
\hline 1 & & $39.1, \mathrm{C}$ & & 42.7 \\
\hline \multirow[t]{2}{*}{2} & $1.79(\mathrm{td}, 13.2,3.7)$ & $36.7, \mathrm{CH}_{2}$ & $2.55(\mathrm{~d}, 16.9)$ & 50.7 \\
\hline & $1.45(\mathrm{~m})$ & & $2.20(\mathrm{~d}, 16.9)$ & \\
\hline \multirow[t]{2}{*}{3} & $1.83(\mathrm{~m})$ & $19.1, \mathrm{CH}_{2}$ & & 201.1 \\
\hline & $1.34(\mathrm{~m})$ & & & \\
\hline \multirow[t]{2}{*}{4} & $1.68(\mathrm{td}, 13.2,3.7)$ & $37.4, \mathrm{CH}_{2}$ & 5.90 (br s) & 127.3 \\
\hline & $1.14(\mathrm{~m})$ & & & \\
\hline 5 & & $75.7, \mathrm{C}$ & & 167.0 \\
\hline 6 & & $79.9, \mathrm{C}$ & & 80.3 \\
\hline 7 & $6.15(\mathrm{~d}, 15.9)$ & $133.4, \mathrm{CH}$ & $5.99(\mathrm{~d}, 16.2)$ & 130.8 \\
\hline 8 & $5.83(\mathrm{dd}, 15.9,6.8)$ & 133.7, $\mathrm{CH}$ & $6.39(\mathrm{~d}, 16.2)$ & 131.4 \\
\hline 9 & $4.44(\mathrm{dq}, 6.8,6.3)$ & $78.4, \mathrm{CH}$ & & 146.8 \\
\hline 10 & $1.34(3 \mathrm{H}, \mathrm{d}, 6.3)$ & $21.6, \mathrm{CH}$ & $4.45(t, 7.5)$ & 73.8 \\
\hline \multirow[t]{2}{*}{11} & $0.84(3 \mathrm{H}, \mathrm{s})$ & $27.8, \mathrm{CH}_{3}$ & $3.65(\mathrm{dd}, 11.4,7.5)$ & 67.3 \\
\hline & & & $3.43(\mathrm{dd}, 11.4,7.5)$ & \\
\hline 12 & $1.08(3 \mathrm{H}, \mathrm{s})$ & $27.1, \mathrm{CH}_{3}$ & $1.05(3 \mathrm{H}, \mathrm{s})$ & 24.7 \\
\hline 13 & $1.20(3 \mathrm{H}, \mathrm{s})$ & 25.7, $\mathrm{CH}_{3}$ & $1.02(3 \mathrm{H}, \mathrm{d}, 1.4)$ & 23.5 \\
\hline 14 & & & $1.92(3 \mathrm{H}, \mathrm{br} \mathrm{s})$ & 19.5 \\
\hline \multirow[t]{2}{*}{15} & & & 5.33 (br s) & 116.4 \\
\hline & & & 5.23 (br s) & \\
\hline $1^{\prime}$ & $4.36(\mathrm{~d}, 7.8)$ & 102.6, $\mathrm{CH}$ & & \\
\hline $2^{\prime}$ & $3.19(\mathrm{dd}, 9.2,7.8)$ & $75.4, \mathrm{CH}$ & & \\
\hline $3^{\prime}$ & $3.22(\mathrm{~m})$ & $77.9, \mathrm{CH}$ & & \\
\hline $4^{\prime}$ & $3.32(\mathrm{~m})$ & $71.5, \mathrm{CH}$ & & \\
\hline $5^{\prime}$ & $3.35(\mathrm{~m})$ & $78.1, \mathrm{CH}$ & & \\
\hline \multirow[t]{2}{*}{$6^{\prime}$} & $3.82(\mathrm{dd}, 11.8,2.4)$ & $62.5, \mathrm{CH}_{2}$ & & \\
\hline & $3.66(\mathrm{dd}, 11.8,5.3)$ & & & \\
\hline
\end{tabular}




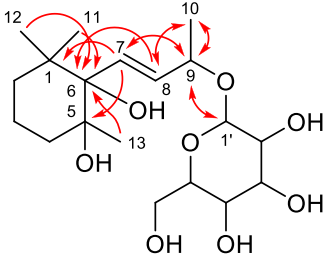

1

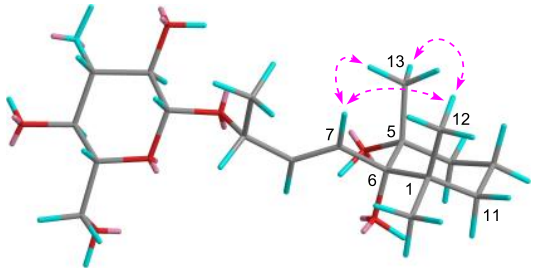

1

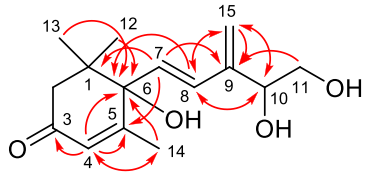

11

Figure 3. Key HMBC (plain) or NOESY (dashed) correlations of compounds $\mathbf{1}$ and $\mathbf{1 1 .}$
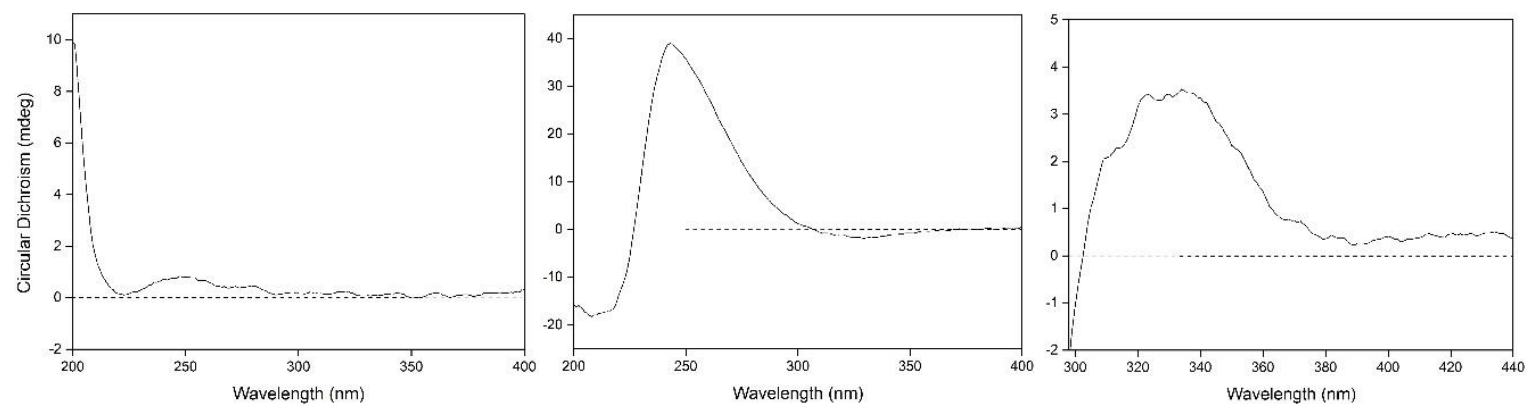

Figure 4. Circular dichroism (CD) spectra of compounds $\mathbf{1}$ (left) and $\mathbf{1 1}$ (middle) and induced circular dichroism (ICD) spectrum of $\mathbf{1 1}$ (right).

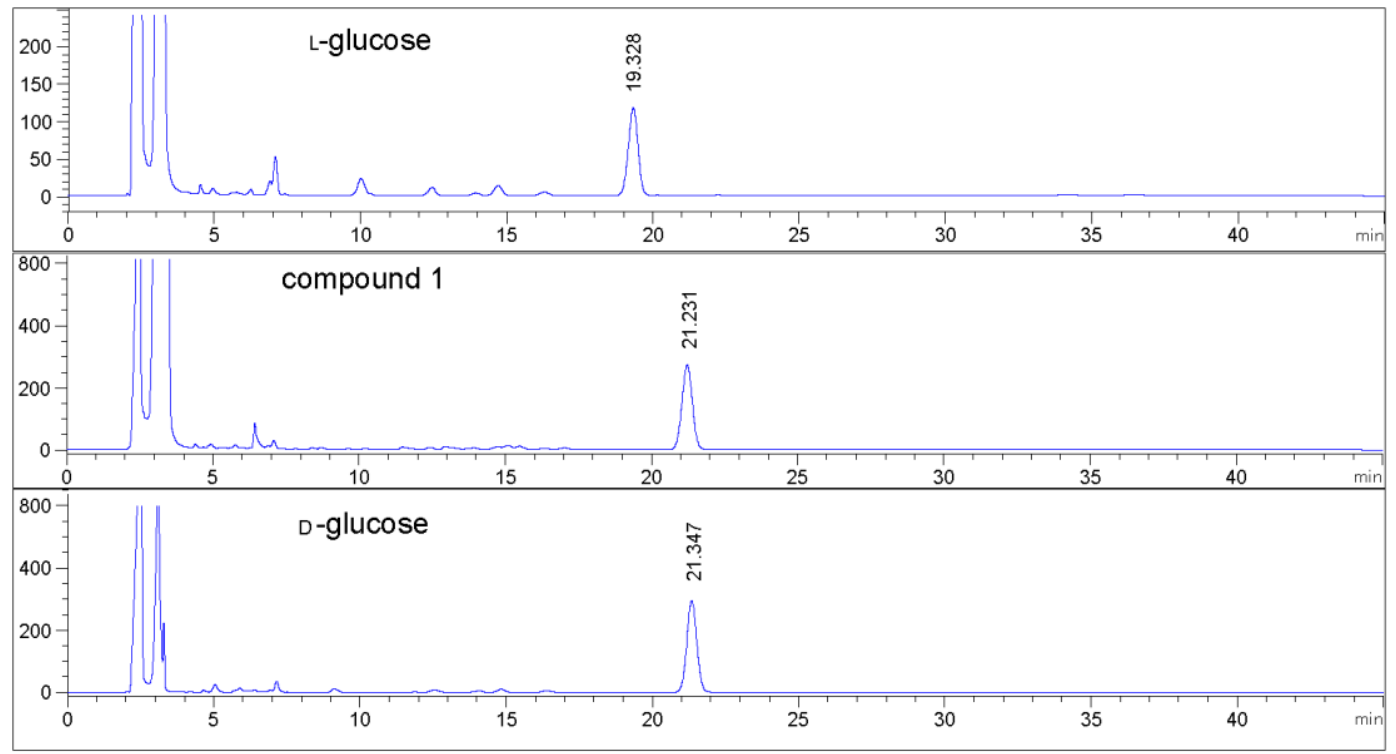

Figure 5. HPLC analytic spectra of glucosyl derivatives.

Compound 11 was acquired as a colorless oil with a positive optical rotation $(+116.2$ in $\mathrm{MeOH})$. The molecular formula $\mathrm{C}_{15} \mathrm{H}_{22} \mathrm{O}_{4}$ was deduced from an HR-ESI-MS peak at $m / z 289.1412[\mathrm{M}+\mathrm{Na}]^{+}$ (calculated for $\mathrm{C}_{15} \mathrm{H}_{22} \mathrm{NaO}_{4}{ }^{+}, 289.1410$ ) (Figure 2), which requires five degrees of unsaturation. The ${ }^{1} \mathrm{H}$ and ${ }^{13} \mathrm{C}$ NMR data (Table 1) suggested that it was an abscisic alcohol derivative in comparison with those of abscisic alcohol $\beta$-D-glucoside (16) [12]. However, compound 11 showed the signals of two olefinic protons at $\delta_{\mathrm{H}} 5.23(1 \mathrm{H}, \mathrm{br} \mathrm{s})$ and $5.33(1 \mathrm{H}, \mathrm{br} \mathrm{s})$, which were typical of a terminal double bond $\left(\mathrm{H}_{2}-15\right)$. The HMBC correlations (Figure 3) from $\delta_{\mathrm{H}} 5.99(1 \mathrm{H}, \mathrm{d}, J=16.2 \mathrm{~Hz}, \mathrm{H}-7)$ to $\delta_{\mathrm{C}} 146.8(\mathrm{C}-9), \mathrm{H}_{2}-15$ to $\delta_{C} 131.4(C-8), 73.8(C-10)$, and C-9 ascertained the terminal double bond between C-9 and C-15. In addition, the HMBC correlations from $\mathrm{H}-10$ to $\mathrm{C}-8, \delta_{\mathrm{H}} 3.65$ and $3.43(1 \mathrm{H}$ each, dd, $J=11.4,7.5 \mathrm{~Hz}$, $\left.\mathrm{H}_{2}-11\right)$ to $C-9$ indicated a vicinal diol moiety connected to C-9. Further, the positive $[\alpha]_{D}$ value and positive Cotton effect at $243 \mathrm{~nm}$ in the CD spectrum (Figure 4) determined the $S$ absolute configuration 
of C-6 $[13,14]$. In order to determine the absolute configuration of C-10, the induced circular dichroism (ICD) spectrum by $\mathrm{Mo}_{2}(\mathrm{OAc})_{4}$ was measured using Snatzke's method [15], which exhibited a positive Cotton effect at $310 \mathrm{~nm}$ after the addition of dimolybdenum tetraacetate in DMSO solution (Figure 4). According to the empirical rule, $\mathrm{C}-10$ was determined to have an $S$ absolute configuration. Therefore, compound 11 was identified as $(6 S, 7 E, 10 S)-\Delta^{9,15}-10$-hydroxyabscisic alcohol.

The new compound $\mathbf{1 1}$ was a rare $\mathrm{C}_{15}$ carotenoid-derived norisoprenoid with a double bond between C-9 and C-15, and its possible biogenetic pathway was proposed, as shown in Figure 6 . Compound 11 is likely generated from $9 E$-abscisic alcohol, the aglycone of compound 16, by oxidation to form an epoxide between C-9 and C-10, and then dehydration to form a double bond between C-9 and $\mathrm{C}-15$ and a hydroxyl group at C-10 under acidic conditions.

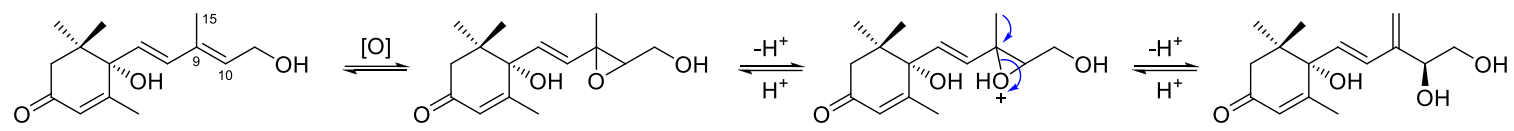

9E-Abscisic alcohol

compound 11

Figure 6. Possible biogenetic pathway of compound 11.

The 14 known compounds were determined as dehydrovomifoliol (2) [16], 3-oxo- $\alpha$-ionol 9-O- $\beta$-D-glucoside (3) [17], roseoside (4) [17], 3-oxo-9-O- $\beta$-D-glucosyloxy-4,6E-megastigmadien (5) [18], 4-oxo- $\beta$-ionol 9-O- $\beta$-D-glucoside (6) [9], cannabiside D (7) [19], dendranthemoside B (8) [20], icariside B2 (9) [21], officinoside A (10) [22], abscisic acid (12) [23], abscisyl $\beta$-D-glucoside (13) [24], 9E-abscisic acid (14) [25], $9 E$-abscisyl $\beta$-D-glucoside (15) [26], and 9E-abscisic alcohol $\beta$-D-glucoside (16) [12] by comparing their spectroscopic data with those reported in the literature (see Supplementary Materials).

Glycosides perform accumulation, storage, and transport roles in aroma volatiles [27]. Herderich et al. [5] hydrolyzed star fruit extract with enzymes and identified $17 \mathrm{C}_{13}$-norisoprenoids by GC-MS, including the aglycones of compounds 3-6,9, and 10. The aglycone of the new compound 1 was elucidated as tobacco's flavor by Wahlberg [8]. Compound $\mathbf{2}$ was previously reported as the flavor of quince [28] and purple passion fruit [29], and this is the first time that it was characterized as star fruit's fragrance. In addition to compound 2, compounds 3-7, 9, and 10 were identified in the genus Averrhoa for the first time. The genin of compound 7 was not previously reported in nature. The peracetylated form of compound $\mathbf{8}$ was isolated from star fruit as an intact glycoconjugate flavor precursor [7].

\section{Materials and Methods}

\subsection{General Experimental Procedures}

ESI-MS spectra were measured on an MDS SCIEX API 2000 LC/MS/MS apparatus (Applied Biosystems Inc., Forster, CA, USA). The HR-ESI-MS spectrum of compound $\mathbf{1}$ was obtained on a Waters Xevo G2-XS QTOF mass spectrometer (Waters MS Technologies, Elstree, Hertfordshire, UK); a full MS scan was performed in the range of $m / z 100-1500 \mathrm{Da}$, the capillary voltage was set at $2.5 \mathrm{kV}$, and the cone voltage was $40 \mathrm{~V}$. Nitrogen gas was used for nebulizer and desolvation. The HR-ESI-MS spectrum of compound $\mathbf{1 1}$ was measured on a Bruker maXis mass spectrometer (Bruker Daltonics GmbH, Bremen, Germany); a full MS scan was performed in the range of $m / z$ 100-2000 Da, the capillary voltage was set at $4.5 \mathrm{kV}$, and the end plate offset voltage was $-500 \mathrm{~V}$. One-dimensional (1D) and two-dimensional (2D) NMR spectra were recorded on a Bruker DRX-500 NMR spectrometer at $25^{\circ} \mathrm{C}$ using solvent residual peaks as references. The ${ }^{1} \mathrm{H}$ NMR spectra were run at $500.13 \mathrm{MHz}$ proton frequency and the spectral width was $7500 \mathrm{~Hz}$. The ${ }^{13} \mathrm{C}$ NMR spectra were run at $125.77 \mathrm{MHz}$ spectrometer frequency and the spectral width was $28,850 \mathrm{~Hz}$. HSQC and HMBC experiments were measured using gradient selected sequences with 512 transients and 2048 data points for each of the 128 increments. The spectral widths were set at $5100 \mathrm{~Hz}$ for ${ }^{1} \mathrm{H}$ and $27,500 \mathrm{~Hz}$ for ${ }^{13} \mathrm{C}$ in the HSQC experiment, and $5100 \mathrm{~Hz}$ for ${ }^{1} \mathrm{H}$ and $27,500 \mathrm{~Hz}$ for ${ }^{13} \mathrm{C}$ in the $\mathrm{HMBC}$ experiment. For the NOESY 
experiment, 128 transients were collected into 1024 data points for each of the 160 increments with a spectral width of $3597 \mathrm{~Hz}$ for both dimensions. Optical rotation and ultraviolet (UV) spectra were acquired on a 343 polarimeter and a Lambda $650 \mathrm{UV} /$ Vis spectrophotometer (Perkin-Elmer, Waltham, MA, USA), respectively. CD spectra were recorded on a Chirascan circular dichroism spectrometer (Applied Photophysics Ltd., Surrey, UK). Silica gel (100-200 mesh) was from Qingdao Haiyang Chemical Co. (Shandong, China), Amberlite XAD-7HP macroporous resin was from Sigma-Aldrich (St. Louis, MO, USA), and Sephadex LH-20 was from GE Healthcare Bio-Sciences AB (Uppsala, Sweden). Authentic D-(+)-glucose and L-(-)-glucose were from Aladdin Industrial Corp. (Shanghai, China). L-Cystein methyl ester hydrochloride was from Shanghai Macklin Biochemical Co. (Shanghai, China). O-Tolylisothiocyanate was from Tokyo Chemical Industry Co. (Tokyo, Japan). Thin layer chromatography (TLC) was conducted on pre-coated silica gel HSGF 254 plates (Jiangyou Silica Gel Development Co., Yantai, China), and visualized by spraying $10 \%$ sulfuric acid in ethanol $(v / v)$ followed by heating. Medium pressure liquid chromatography (MPLC) was performed on an EZ Purifier (Lisure Science, Suzhou, China) and the column used was a $400 \mathrm{~mm} \times 25 \mathrm{~mm}$ inner diameter (i.d.) Chromatorex RP-18 SMB100, particle size 20-45 $\mu \mathrm{m}$ (Shanghai Lisui E-Tech Co., Shanghai, China). HPLC was conducted on a LC3000 set connected to a UV3000 scanning spectrophotometer detector (Beijing ChuangXin TongHeng Sci. and Tech. Co., Beijing, China) and the columns used were Cosmosil 5C18-MS-II ( $250 \mathrm{~mm} \times 4.6 \mathrm{~mm}$ i.d., particle size $5 \mu \mathrm{m}$, Nacalai Tesque, Inc., Kyoto, Japan) for analysis and YMC-Pack ODS-A ( $250 \mathrm{~mm} \times 20 \mathrm{~mm}$ i.d., particle size $5 \mu \mathrm{m}$, YMC Co., Kyoto, Japan) for preparation.

\subsection{Plant Material}

Fresh ripe star fruits (sweet in taste) were collected from an orchard $\left(23^{\circ} 06^{\prime} 70.44^{\prime \prime} \mathrm{N}\right.$ and $113^{\circ} 35^{\prime} 56.02^{\prime \prime}$ E) in Xiaozhou Village, Haizhu District, Guangzhou in December of 2012.

\subsection{Extraction and Isolation}

The fresh fruits $(105 \mathrm{~kg})$ were cut to pieces and immediately soaked in $95 \%$ ethanol. The solution was filtrated after two days. The extraction steps were conducted three times. The combined solutions were concentrated under vacuum to give a brown syrup. The syrup was diluted with water and partitioned with ethyl acetate and then $n$-butanol. The solutions were evaporated to dryness to afford an ethyl acetate soluble fraction (77.4 g) and an $n$-butanol soluble fraction (590.2 g). The latter fraction was passed through an XAD-7HP macroporous resin column eluted with water and then $95 \%$ ethanol. The ethanol eluent was concentrated to dryness to result in an ethanol eluate $(128.1 \mathrm{~g})$. The eluate and ethyl acetate soluble fractions were combined and then subjected to silica gel column chromatography (CC) eluted with a chloroform/methanol gradient system $(v / v, 1: 0,16 \mathrm{~L}$; 95:5, $22.4 \mathrm{~L}$; 9:1, 38.4 L; and $0: 1,16 \mathrm{~L}$ ) to yield fractions 1-9 after being pooled according to their TLC profiles. Fraction 5 $(19.0 \mathrm{~g})$ was separated by silica gel CC eluted with a chloroform/methanol gradient system $(v / v, 1: 0$, $6 \mathrm{~L} ; 9: 1,7 \mathrm{~L} ; 85: 15,6 \mathrm{~L} ; 4: 1,8 \mathrm{~L} ; 7: 3,6 \mathrm{~L} ; 3: 2,6 \mathrm{~L}$; and 1:1, $10 \mathrm{~L}$ ) to provide fractions 5-1-5-7. Fraction 5-4 $(65 \mathrm{mg})$ was separated by LH-20 CC eluted with methanol and then purified by HPLC using $62 \%$ methanol/water $(v / v)$ as the mobile phase at a flow rate of $5 \mathrm{~mL} / \mathrm{min}$ to yield compounds 14 $\left(t_{\mathrm{R}}=22 \mathrm{~min}, 4 \mathrm{mg}\right)$ and $12\left(t_{\mathrm{R}}=25 \mathrm{~min}, 11 \mathrm{mg}\right)$. Fraction $6(6.0 \mathrm{~g})$ was separated by MPLC using a methanol/water gradient system $(v / v, 3: 7,2: 3,1: 1,3: 2,7: 3,4: 1$, and 1:0, each $2 \mathrm{~L})$ as the mobile phase to yield fractions 6-1-6-6. Fraction 6-5 (27 mg) was purified by HPLC using 30\% methanol/water $(v / v)$ as the mobile phase at $5 \mathrm{~mL} / \mathrm{min}$ to yield compound $11\left(t_{\mathrm{R}}=51 \mathrm{~min}, 8 \mathrm{mg}\right)$. Fraction 6-6 $(75 \mathrm{mg})$ was separated by LH-20 CC eluted with methanol and then purified by HPLC using $30 \%$ methanol/water $(v / v)$ as the mobile phase at $5 \mathrm{~mL} / \mathrm{min}$ to result in compound $2\left(t_{\mathrm{R}}=65 \mathrm{~min}, 9 \mathrm{mg}\right)$. Fraction 8 $(2.7 \mathrm{~g})$ was separated by MPLC eluted with a methanol/water gradient system to provide fractions 8-1-8-10. Fraction 8-5 (250 mg) was separated by LH-20 CC eluted with methanol and then purified by HPLC using $12 \%$ methanol/water $(v / v)$ as the mobile phase at $5 \mathrm{~mL} / \mathrm{min}$ to yield compound $9\left(t_{\mathrm{R}}=70 \mathrm{~min}, 4 \mathrm{mg}\right)$. Fraction 8-9 $(69 \mathrm{mg})$ was separated by LH-20 CC eluted with methanol and 
then purified by HPLC using $39 \%$ methanol/water $(v / v)$ as the mobile phase at $5 \mathrm{~mL} / \mathrm{min}$ to yield compounds $5\left(t_{\mathrm{R}}=62 \mathrm{~min}, 10 \mathrm{mg}\right)$ and $3\left(t_{\mathrm{R}}=70 \mathrm{~min}, 5 \mathrm{mg}\right)$. Fraction 8-10 (97 mg) was separated by LH-20 CC and then purified by HPLC using 39\% methanol/water $(v / v)$ as the mobile phase at $5 \mathrm{~mL} / \mathrm{min}$ to yield compound $6\left(t_{\mathrm{R}}=120 \mathrm{~min}, 9 \mathrm{mg}\right)$. Fraction $9(150.2 \mathrm{~g})$ was subjected to silica gel CC eluted with a chloroform/methanol gradient system $(v / v, 9: 1,15 \mathrm{~L} ; 85: 15,23 \mathrm{~L} ; 4: 1,20 \mathrm{~L} ; 7: 3,38 \mathrm{~L}$; 3:2, $40 \mathrm{~L}$; and 1:1, 59 L) to provide fractions 9-1-9-8. Fraction 9-2 (1.25 g) was separated by MPLC to give fractions 9-2-1-9-2-17. Fraction 9-2-5 (56 mg) was purified by HPLC using 20\% methanol/water $(v / v)$ as the mobile phase at $5 \mathrm{~mL} / \mathrm{min}$ to yield compounds $8\left(t_{\mathrm{R}}=76 \mathrm{~min}, 5 \mathrm{mg}\right)$ and $4\left(t_{\mathrm{R}}=81 \mathrm{~min}\right.$, $15 \mathrm{mg}$ ). Fraction 9-2-8 (82 mg) was separated by LH-20 CC and then purified by HPLC using 14\% acetonitrile/water $(v / v)$ as the mobile phase at $6 \mathrm{~mL} / \mathrm{min}$ to yield compounds $10\left(t_{\mathrm{R}}=118 \mathrm{~min}, 6 \mathrm{mg}\right)$, $15\left(t_{\mathrm{R}}=129 \mathrm{~min}, 8 \mathrm{mg}\right)$, and $13\left(t_{\mathrm{R}}=139 \mathrm{~min}, 10 \mathrm{mg}\right)$. Fraction 9-2-9 $(120 \mathrm{mg})$ was separated by LH-20 CC and then purified by HPLC using $15 \%$ acetonitrile/water $(v / v)$ as the mobile phase at $6 \mathrm{~mL} / \mathrm{min}$ to result in compounds $1\left(t_{\mathrm{R}}=61 \mathrm{~min}, 5 \mathrm{mg}\right)$ and $16\left(t_{\mathrm{R}}=64 \mathrm{~min}, 12 \mathrm{mg}\right)$. Fraction 9-3 (6.13 g) was separated by MPLC to provide fractions 9-3-1-9-3-24. Fraction 9-3-12 (57 mg) was separated by LH-20 CC and then purified by HPLC using $15 \%$ acetonitrile/water $(v / v)$ as the mobile phase at $6 \mathrm{~mL} / \mathrm{min}$ to yield compound 7 ( $\left.t_{\mathrm{R}}=61 \mathrm{~min}, 13 \mathrm{mg}\right)$.

(5R,6S,7E,9R)-5,6,9-Trihydroxy-7-megastigmene 9-O- $\beta$-D-glucoside (1): Colorless oil; $[\alpha]_{\mathrm{D}}^{20}+24.7$ (c 0.19 , $\mathrm{MeOH}) ; \mathrm{CD}(\mathrm{MeOH}) \Delta \varepsilon 247$ (+0.97); HR-ESI-MS $m / z 389.4614[\mathrm{M}-\mathrm{H}]^{-}$(calculated for $\mathrm{C}_{19} \mathrm{H}_{33} \mathrm{O}_{8}{ }^{-}$, 389.4605, error $-2.3 \mathrm{ppm})$; ESI-MS $m / z 413[\mathrm{M}+\mathrm{Na}]^{+}, 389[\mathrm{M}-\mathrm{H}]^{-}$, and $425\left[\mathrm{M}+\mathrm{Cl}^{-}{ }^{-}{ }^{1} \mathrm{H} \mathrm{NMR}\right.$ $(500 \mathrm{MHz})$ and ${ }^{13} \mathrm{C}$ NMR $(125 \mathrm{MHz})$ data in $\mathrm{CD}_{3} \mathrm{OD}$, see Table 1.

$(6 S, 7 E, 10 S)-\Delta^{9,15}-10-H y d r o x y a b s c i s i c$ alcohol (11): Colorless oil; $[\alpha]_{\mathrm{D}}^{20}+116.2$ (c 1.00, MeOH); $\mathrm{UV}(\mathrm{MeOH}) \lambda_{\max } \mathrm{nm}(\log \varepsilon) 230$ (4.08); CD (MeOH) $\Delta \varepsilon 208$ (-10.51), $243(+22.43)$, and 329 (-1.06); HR-ESI-MS $m / z 289.1412[\mathrm{M}+\mathrm{Na}]^{+}$(calculated for $\mathrm{C}_{15} \mathrm{H}_{22} \mathrm{NaO}_{4}{ }^{+}, 289.1410$, error $-0.7 \mathrm{ppm}$ ); ESI-MS $m / z 267[\mathrm{M}+\mathrm{H}]^{+}, 289[\mathrm{M}+\mathrm{Na}]^{+}, 265[\mathrm{M}-\mathrm{H}]^{-}$, and $301[\mathrm{M}+\mathrm{Cl}]^{-} ;{ }^{1} \mathrm{H} \mathrm{NMR}(500 \mathrm{MHz})$ and ${ }^{13} \mathrm{C}$ NMR $(125 \mathrm{MHz})$ data in $\mathrm{CD}_{3} \mathrm{OD}$, see Table 1.

\subsection{Acid Hydrolysis}

Acid hydrolysis was conducted following our previously reported procedures [30]. In brief, compound $1(1 \mathrm{mg})$ was dissolved in $5 \mathrm{~mL}$ of $2 \mathrm{M}$ aqueous hydrochloride and refluxed at $95{ }^{\circ} \mathrm{C}$ for $4 \mathrm{~h}$. After removal of the solution under vacuum, $5 \mathrm{~mL}$ of water was added and partitioned with $5 \mathrm{~mL}$ of ethyl acetate three times. The aqueous layer was concentrated to dryness to yield a residue. The residue, authentic D-glucose, and L-glucose were individually dissolved in $1 \mathrm{~mL}$ of pyridine containing $1 \mathrm{mg} / \mathrm{mL}$ L-cystein methyl ester hydrochloride. After each solution was heated at $60^{\circ} \mathrm{C}$ for $1 \mathrm{~h}, 2 \mathrm{~mL}$ of $O$-tolylisothiocyanate was added, heated at $60^{\circ} \mathrm{C}$ for $1 \mathrm{~h}$, and then concentrated to dryness. Each residue was dissolved in $1 \mathrm{~mL}$ of methanol and filtrated and analyzed by an Agilent Infinity $1260 \mathrm{HPLC}$ at the wavelength of $254 \mathrm{~nm}$ and a $40{ }^{\circ} \mathrm{C}$ oven temperature. The column used was a Cosmosil 5C18-MS-II with acetonitrile/water/acetic acid $(v / v, 22: 78: 0.1)$ as the mobile phase at a flow rate of $0.8 \mathrm{~mL} / \mathrm{min}$ for $60 \mathrm{~min}$, followed by washing with $90 \%$ acetonitrile/water $(v / v)$.

\subsection{Induced $\mathrm{CD}$ Spectrum by $\mathrm{Mo}_{2}(\mathrm{OAc})_{4}$}

According to the published procedure [15], about 1:1 diol-to-molybdenum mixtures were prepared using $0.66 \mathrm{mg} / \mathrm{mL}$ of compound 11. The first CD spectrum was recorded soon after mixing and its evolution monitored for $30 \mathrm{~min}$. The sign of the diagnostic band at $310 \mathrm{~nm}$ correlated with the absolute configuration of the diol moiety.

\section{Conclusions}

The fresh fruit of Averrhoa carambola (star fruit) possesses a fascinating and unique flavor, and carotenoid-derived $\mathrm{C}_{13^{-}}$and $\mathrm{C}_{15}$-norisoprenoids contribute greatly to the flavor of star fruit. 
However, the exact structural information about the glycosidically bound precursors in star fruit was deficient. Our study on fresh star fruit led to the isolation of two new (1 and 11) and 14 known carotenoid-derived $\mathrm{C}_{13^{-}}$and $\mathrm{C}_{15}$-norisoprenoids, of which 12 were in glucoside form. In addition to the two new compounds, compound 2 and seven known $C_{13}$-norisoprenoid glucosides (3-7, 9, and 10) were identified from the genus Averrhoa for the first time. The new compound $\mathbf{1 1}$ was a rare $\mathrm{C}_{15}$ carotenoid-derived norisoprenoid with a terminal double bond between C-9 and C-15. In view of the previous reports of the aglycones of compounds 1,3,7, and 8 and compound 2 itself as volatile flavor components in star fruit [6] or other fruits [8,28,29], it could be concluded that some of the 12 $\mathrm{C}_{13}$ - and $\mathrm{C}_{15}$-norisoprenoid glucosides were carotenoid-derived flavor precursors in star fruit.

Supplementary Materials: The following are available online. Figures S1-S5: 1D and 2D NMR spectra of compound 1. Figure S6-S9: 1D and 2D NMR spectra of compound 11. Spectroscopic data of 14 known compounds.

Author Contributions: X.J. and D.Y. contributed equally to this study; Formal analysis and investigation, X.J., D.Y., and Y.Y.; Resources, D.Y.; Writing-Original draft preparation, X.J.; Supervision and writing-Review and editing, H.X. All authors read and approved the final manuscript.

Funding: This study was funded by the Natural Science Foundation of Guangdong Province (2018A030310199), the National Basic Research Program of China (2013CB127106), and the President Foundation of Guangdong Academy of Agricultural Sciences (No. 201904).

Conflicts of Interest: The authors declare no conflict of interest.

\section{References}

1. Lim, T.K. Edible Medicinal and Non-Medicinal Plants, Fruits; Springer: Berlin, Germany, 2012.

2. Wilson, C.W.; Shaw, P.E.; Knight, R.J.; Nagy, S.; Klim, M. Volatile constituents of carambola (Averrhoa carambola L.). J. Agric. Food Chem. 1985, 33, 199-201. [CrossRef]

3. Fröhlich, O.; Schreier, P. Additional volatile constituents of carambola (Averrhoa carambola L.) fruit. Flavour Fragr. J. 1989, 4, 177-184. [CrossRef]

4. Macleod, G.; Ames, J.M. Volatile components of starfruit. Phytochemistry 1990, 29, 165-172. [CrossRef]

5. Herderich, M.; Neubert, C.; Winterhalter, P.; Schreier, P.; Skouroumounis, G.K. Identification of $\mathrm{C}_{13}$-norisoprenoid flavour precursors in starfruit (Averrhoa carambola L.). Flavour Fragr. J. 1992, 7, 179-185. [CrossRef]

6. Winterhalter, P.; Schreier, P. The generation of norisoprenoid volatiles in starfruit (Averrhoa carambola L.): A review. Food Rev. Int. 1995, 11, 237-254. [CrossRef]

7. Lutz, A.; Winterhalter, P.; Schreier, P. The structure of a new ionone glucoside from starfruit (Averrhoa carambola L.). Nat. Prod. Lett. 1993, 3, 95-99. [CrossRef]

8. Wahlberg, I.; Eklund, A.M.; Enzell, C.R.; Berg, J.E. Tobacco chemistry. 66. (5R,6S,7E,9S)-7-megastigmene5,6,9-triol, a new constituent of Greek tobacco. Acta Chem. Scand. B 1987, 41, 455-458. [CrossRef]

9. Pabst, A.; Barron, D.; Sémon, E.; Schreier, P. 4-Oxo- $\beta$-ionol and linalool glycosides from raspberry fruits. Phytochemistry 1992, 31, 4187-4190. [CrossRef]

10. Yoshikawa, M.; Shimada, H.; Saka, M.; Yoshizumi, S.; Yamahara, J.; Matsuda, H. Medicinal foodstuffs. V. Moroheiya. (1): Absolute stereostructures of corchoionosides A, B, and C, histamine release inhibitors from the leaves of Corchorus olitorius L. (Tiliaceae). Chem. Pharm. Bull. 1997, 45, 464-469. [CrossRef]

11. Matsunami, K.; Otsuka, H.; Takeda, Y. Structure revisions of blumenol C glucoside and byzantionoside B. Chem. Pharm. Bull. 2010, 58, 438-441. [CrossRef]

12. Gunawardena, D.C.; Jayasinghe, L.; Fujimoto, Y. Phytotoxic constituents of the fruits of Averrhoa carambola. Chem. Nat. Comp. 2015, 51, 532-533. [CrossRef]

13. Zaharia, L.I.; Gai, Y.; Nelson, K.M.; Ambrose, S.J.; Abrams, S.R. Oxidation of $8^{\prime}$-hydroxy abscisic acid in black Mexican sweet maize cell suspension cultures. Phytochemistry 2004, 65, 3199-3209. [PubMed]

14. Lutz, A.; Winterhalter, P. Isolation of additional carotenoid metabolites from quince fruit (Cydonia oblonga Mill.). J. Agric. Food Chem. 1992, 40, 1116-1120. [CrossRef]

15. Politi, M.; De Tommasi, N.; Pescitelli, G.; Bari, L.D.; Morelli, I.; Braca, A. Structure and absolute configuration of new diterpenes from Lavandula multifida. J. Nat. Prod. 2002, 65, 1742-1745. [CrossRef] [PubMed] 
16. Kai, H.; Baba, M.; Okuyama, T. Two new megastigmanes from the leaves of Cucumis sativus. Chem. Pharm. Bull. 2007, 55, 133-136. [CrossRef] [PubMed]

17. Mohamed, K.M.; Mohamed, M.H.; Ohtani, K.; Kasai, R.; Yamasaki, K. Megastigmane glycosides from seeds of Trifolium alexandrinum. Phytochemistry 1999, 50, 859-862. [CrossRef]

18. Khan, S.H.; Mosihuzzaman, M.; Nahar, N.; Rashid, M.A.; Rokeya, B.; Ali, L.; Khan, A.K.A. Three megastigmane glucosides from the leaves of Pterospermum semisagittatum. Pharm. Biol. 2003, 41, 512-515. [CrossRef]

19. Wang, Y.; Zhu, H.; Wang, D.; Cheng, R.; Yang, C.; Xu, M.; Zhang, Y. A new phloroglucinol glucoside from the whole plants of Glochidion eriocarpum. Bull. Korean Chem. Soc. 2014, 35, 631-634. [CrossRef]

20. Otsuka, H.; Takeda, Y.; Yamasaki, K.; Takeda, Y. Structural elucidation of dendranthemosides A and B: Two new $\beta$-ionone glucosides from Dendranthema shiwogiku. Planta Med. 1992, 58, 373-375. [CrossRef] [PubMed]

21. Chen, B.; Li, B.G.; Zhang, G.L. Glycosides from Erigeron breviscapus. Acta Bot. Sin. 2002, 44, 344-348.

22. Murakami, T.; Kishi, A.; Yoshikawa, M. Medicinal flowers. IV. Marigold. (2): Structures of new ionone and sesquiterpene glycosides from Egyptian Calendula officinalis. Chem. Pharm. Bull. 2001, 49, 974-978. [CrossRef]

23. Wang, X.; Hu, Y.; Yuan, D.; Fu, H. Chemical constituents from the flowers of Rhododendron molle G. Don. J. Chin. Pharm. Sci. 2014, 23, 94-98. [CrossRef]

24. Kato-Noguchi, H.; Tanaka, Y.; Murakami, T.; Yamamura, S.; Fujihara, S. Isolation and identification of an allelopathic substance from peel of Citrus junos. Phytochemistry 2002, 61, 849-853. [CrossRef]

25. Ramos, M.D.R.; Jerz, G.; Villanueva, S.; López-Dellamary, F.; Waibel, R.; Winterhalter, P. Two glucosylated abscisic acid derivates from avocado seeds (Persea americana Mill. Lauraceae cv. Hass). Phytochemistry 2004, 65, 955-962. [CrossRef] [PubMed]

26. Yamauchi, S.; Abe, F.; Kinoshita, Y. Germination inhibitors in Citrus unshu fruit peelings: (+)-abscisyl $\beta$-D-glucopyranoside. Biosci. Biotechnol. Biochem. 1995, 59, 1968. [CrossRef]

27. Winterhalter, P.; Skouroumounis, G.K. Glycoconjugated aroma compounds: Occurrence, role and biotechnological transformation. Adv. Biochem. Eng. Biotechnol. 1997, 55, 73-105. [PubMed]

28. Winterhalter, P.; Schreier, P. Free and bound $\mathrm{C}_{13}$ norisoprenoid in quince (Cydonia oblonga, Mill.) fruit. J. Agric. Food Chem. 1988, 36, 1251-1256. [CrossRef]

29. Winterhalter, P. Bound terpenoids in the juice of the purple passion fruit (Passiflora edulis Sims). J. Agric. Food Chem. 1990, 38, 452-455. [CrossRef]

30. Xiao, Y.; Xie, H.; Zhao, L.; Gou, P. Acyl flavone and lignan glucosides from Leontopodium leontopodioides. Phytochem. Lett. 2016, 17, 247-250. [CrossRef]

Sample Availability: Samples of the compounds 1-16 are available from the authors.

(C) 2019 by the authors. Licensee MDPI, Basel, Switzerland. This article is an open access article distributed under the terms and conditions of the Creative Commons Attribution (CC BY) license (http:/ / creativecommons.org/licenses/by/4.0/). 